\section{Botanists of the Second Millennium B.c.}

AN interesting short paper by Prof. F. E. Weiss (J. Roy. Hort. Soc., 66, Pt. 2, February 1941) directs attention to the "Court of Flowers" in the Festal Temple of Thutmosis III (1501-1447 B.c.) at Karnak. This ruler aspired to, and attained by conquest, a considerable empire in Syria and Palestine. $\mathrm{He}$ appears to have been unique in that he ordered botanical exploration to follow totalitarian imposition, and published his results as bas-reliefs upon the walls of the Court of Flowers at Karnak. Many species are unidentifiable, but others cannot be mistaken. These include the blue water lily, Nymphcea corulea, the pomegranate, vine, two species of arum ( $A$. italicum and $A$. Dracunculus), a species of Kalanchoë and one of Iris. The fruits of sycamore (Ficus sycomorus) and a capitulum of Chrysanthemum coronarium are less certain, though probable, namings. It is rather curious that some of the species are now regarded as native in Egypt, but this lithological publication of botanical geography distinctly speaks in hieroglyphic inscription of "all the beautiful flowers which the power of His Majesty has collected when His Majesty was making war on upper Palestine so as to conquer the countries".

\section{Food from the Poppy}

Temperate regions have relatively few oil-yielding plants, and under the stress of war-time needs, Dr. R. Melville makes the interesting suggestion (Gard. Chron., Feb. 8) that the oil (opium) poppy, Papaver somniferum, would be a suitable crop to grow in Great Britain as a source of fatty nourishment. The seeds have a pleasant, nutty flavour, and contain about 50 per cent of edible oil, with 20 per cent of protein. It is thought that yields of 8 ewt. of seed per acre should be possible in the climate of Great Britain. The seeds do not contain any toxic or narcotic substances, and the most potent vindication of the suggestion is that about twenty acres of the crop used to be cultivated regularly in the Isle of Axholme.

\section{Czechoslovakia: Twenty Years of Independence}

UNDER the above title, Prof. R. J. Kerner of the University of California, Berkeley, U.S.A., has edited a comprehensive and frank appraisal of the cultural, scientific, educational and social progress achieved by the Czechoslovak nation during the two decades it was in charge of its own destinies (University of California Press. Pp. xxii +504 . 5 dollars. 1940). As this work of more than five hundred pages shows, the record is a remarkable one and its very greatness makes all the more poignant the circumstances whereby the nation lost its independence. In producing this important work Prof. Kerner had the co-operation of twenty distinguished British, American and Czechoslovak scholars possessing firsthand knowledge of their subject. Thus, Prof. Aleš Hrdlička, of the Smithsonian Institution, writes authoritatively on Czechoslovak anthropology. Other writers trace the nation's history, its humanitarian progress, educational policy, music, arts, science and literature.
There are sections on the Little Entente, Czech democracy, social and religious legislation, and a valuable chronology tracing the fundamental happenings which concern the Czechoslovak peoples from 500 B.c., when Gaulic-Celtic tribes inhabited the land, "until July 21, 1940, when the new republic was recognized by Great Britain". Czechoslovakia is not a dead issue, for within the limits of that State and integrated in that people are the funda. mentals of all that democratic Governments believe in and all that individual right holds as its standard.

\section{The Resources of India}

A RECORD and a review, 1939-1940, "India at War" by Sir George Dunbar, with a foreword by FieldMarshal Lord Birdwood, which has just been issued by the Ministry of Information, acquires further interest from recent developments and in the Near and Far East. Sir George Dunbar reviews briefly the help which India has given and is giving in the war against Nazism, including the expansion of her fighting forces, the loyal response of the Indian States and India's economic effort. Great increases are being made in the fighting services, but the most valuable and immediate help India can give is industrial. Sir George reviews India's potential economic reserves in relation to strategy and the conservation of shipping, stressing the importance of her contribution in oils and fats, jute, rubber, hides and skins, etc., as well as the striking development of the iron and steel industry. India is computed to be turning out 90 per cent of her own requirements as well as meeting overseas orders for ammunition, explosives, military equipment and clothing, while the manufacture of aluminium is beginning and aircraft construction is under consideration.

\section{The Grand Coulee Dam}

ON March 22 the official opening took place of the great hydro-electric and irrigation scheme on the Columbia River, Washington, across which the Grand Coulee Dam has been erected. The River Columbia rises in the Rocky Mountains in British Columbia, and after crossing the Canadian boundary flows through the State of Washington to the Pacific Ocean. Its lower courses form the boundary between Washington and Oregon. The scheme has been designed for the generation of electric current and for irrigation purposes. The concrete dam, which impounds water in the 150 -mile stretch up to the Canadian boundary, is $4,200 \mathrm{ft}$. long with a maximum height of $553 \mathrm{ft}$. Its mass is greater than the Boulder Dam, and its construction - details of which are now being published in the Engineer-has taken about eight years.

When completed there will be two power houses with twenty-one generators with a total capacity of about $1,974,000 \mathrm{kw}$, but the first load was of only about $10,000 \mathrm{kw}$. At the west side of the dam will be a pumping house with twelve large electrically driven pumps raising water from the reservoir into a vast balancing basin from which the water will be distributed by a series of canals, over an area of 